\title{
Genre Studies in Russian Literary Research: Achievements and Challenges
}

\author{
NATALIA TULIAKOVA \\ NATALIA NIKITINA
}

\begin{abstract}
Genre has been one of the key categories for Russian literary studies ever since the late nineteenth century, creating a long tradition of artistic, critical and scientific interpretation. The present paper aims to outline major findings of Russian scholars in the field of genre studies and to account for current pitfalls, suggesting a solution. Russian scholars have contributed noticeably to both constructing the theory of genre in general and establishing the laws and genesis of many separate genres. Historical poetics, the Russian Formalists, Bakhtin's school and structuralism worked out the principles of generic evolution and explained the nature of the genre category. Still, currently Russian genology faces a number of challenges, among which is the inability to work out a universal approach to genre nomination and attribution, which causes inconsistent and unverified results. When it comes to describing new genres, most troubling is the choice of deductive method in genre analysis and a narrow specialist approach to each genre leading to inconclusive or biased results. The paper suggests that these challenges can be overcome by turning to the heritage of the classical Russian literary science and taking advantage of comparative and inductive methods proponed by it.
\end{abstract}

Keywords: genre; genre studies; literary studies; genre model

\section{Introduction}

The category of genre is arguably a central one for literary studies (Domínguez 2009). Although in the late twentieth century the category had been for a while denied its key status by poststructuralists, it ultimately regained its positions as scholars realized again its meaningful potential. Russian scholars have significantly contributed to the theory of genre, having formulated several major postulates and thoroughly studied a large number of genres. The aim of the present paper is to outline the milestone achievements of Russian scholars and point out some challenges that have to be overcome in the sphere of genology. The analysis of deficiencies is important for a broader look at the 
current state of affairs and will make it possible to suggest solutions to the existing problems.

The paper will first identify the most important ideas concerning genre developed by Russian researchers. Then the present situation in genology will be analyzed in order to identify current challenges and to account for them. We argue that the drawbacks of recent research related to genre are caused by the whole set of practices, criticized by Yuri Lotman for 'narrow specialism,' when an expert on Russian literature is entitled not to compare with western literature or to benefit from using textology or metrics (Lotman 2012a: 765), and by deductive approach to genre. Finally, we will suggest some solutions to rectify the situation lying primarily in applying the comparative method.

\section{Emergence of Genre Interest}

The category of genre in Russian literary studies has been central for a long time. Attention to genre was observed, on par with European interest in the category, already in the first half of the nineteenth century. Although early poetic dictionaries treated genres from the point of view of prescriptive norms (Ostolopov 1921; Milyutin 1831), writing practices included numerous experiments in the genre sphere, which called for reconsideration of the terms.

The Romantic shift from prescriptive poetics, which dictated following generic conventions, coincided with similar processes in European literature and was partly stimulated by them. It meant that Russian writers, as well as western ones, had to work out new methods of writing, as the value of a work of art was no longer directly linked to following genre patterns (Burlina 1987: 30). On the contrary, the more original, unpredictable the text was, the more it was appreciated. For Romantic writers (V. Odoevsky, N. Kukolnik, and others) genre was a category to be contemplated and construed by mutual efforts of the writer and the reader. This resulted in modifying familiar forms and experimenting with their perception. At the same time, there appeared new works of art that did not follow traditional generic conventions. These texts were to be called with new names, as old labels did not suit brand-new forms. This led to the emergence of such genres as legend ('legenda'), dramatic fantasy ('dramaticheskaya fantasia), fragment ('otryvok'). Thus, a new terminological system was emerging and working itself out (Krylov 2008: 223). As a result, genres attracted attention of many writers and literary critics and were actively debated.

Many genres emerged and were contemplated simultaneously. To illustrate, Vladimir Odoevsky researched folk genres and suggested the ways how they can be employed in literature, and then wrote a number of works based on folk 
models. Another example is Nikolay Polevoy, who in 1826 coined the term 'svyatochny rasskaz' (Christmas tale) and described its constituent features, thus commencing the tradition of literary versions of Christmas tales in Russia. But in fact, the central position in genre debates of the epoch was occupied by povest' (novella) and its variants. Russian Romantics exploited the potential of fantastic novella, historical novella, and the realistic novella, which becomes a leading genre in the near future (Alexander Pushkin, Nikolai Gogol, Ivan Turgenev, and others).

\section{Genre Studies as a Discipline: Major Findings, Current Challenges}

In the second half of the nineteenth century Russian genre system became more stable. During this period genres started to be empirically studied, with the role of the writer and critic differentiated; the figure of the critic was later substituted with that of a scholar. Significant contribution into the status of genre studies belongs to the school of historical poetics and Alexander Veselovsky, who made the term 'genre' an integral part of literary studies (Zakharov 2007: 19). In the 1880s Veselovsky delivered lectures on the theory of poetic genres in their historical development at Saint-Petersburg university, stressing that comparison should become a foundation of every research, and no literary event or text should be studied in isolation. In the centre of his book (Veslovsky 2004) is the question of the evolution of genres in world literature. The leitmotif of his work - that literary studies should establish the 'ratio' of personal contribution and tradition - is first and foremost applied to the category of genre, and has been a key issue ever since.

Every school of literary studies in Russia has drawn from Veselovsky's work. Olga Freidenberg worked on establishing relations between genres and rituals (Freidenberg 1936). Yury Tynyanov analyzed the interaction of literary genres and 'byt' (daily routines) (Tynyanov 1977). Structuralists sought to place genres within the cultural background of the epoch (Lotman 1977).

The beginning of the twentieth century was remarkable for the flourishing of literary thought in different areas, including genre studies. The first half of the century became a true milestone in genre theory. The Russian Formalists' and Mikhail Bakhtin's achievements may be considered a major breakthrough.

The Russian Formalists, first of all, gave several definitions to the term 'genre' that are still in use and have not been surpassed in clarity. Boris Tomashevsky defined genre as "the entity of literary works united by a system of featuring devices, some of which dominate" (Tomashevsky 1925: 162).

Translation here and further is done by Natalia Tuliakova. 
Later, Viktor Shklovsky synthesized the previous ideas by defining the genre as a system of conventions (Shklovsky 1974: 755). Another essential question that the Russian Formalists tried to answer was the nature of genre genesis. Yuri Tynyanov outlined some important mechanisms of generic evolution (Tynyanov 1977), describing how genres move from the periphery to the centre, from the sphere of everyday life to literature. The principle of studying a genre in the cultural context of the epoch (Akhrieva 2014: 30), the necessity of analyzing any text from the viewpoint of tradition, thus establishing the degree of its novelty and originality, is still in use (Tamarchenko 2012: 5; Tsytsarkina 2008: 106).

One more important thesis developed at the time concerned the question what properties should be considered essential when identifying this or that genre. Tynyanov stated that the genre is defined by secondary, formal features (Tynyanov 1977) that the author uses automatically. Boris Eikhenbaum argued in relation to constituent properties of the genre that "any element of the material can serve as a dominant of the construction" (Eikhenbaum 1969: 274). It means that if the length of the text is important in one genre, it is not necessarily an indicator of the genre in other cases.

From the practical perspective, the Russian Formalists expressed keen interest in the genres of the novel and the novella. The Formalists presented a thorough analysis of the novella as such, analyzing its construction, system of motives, genesis (Reformatsky 1922; Petrovsky 1927; Eikhenbaum 1927). It seems that nothing particularly new has been added ever since concerning its theory.

As for Mikhail Bakhtin, his genre theory is considered to be one of his most valuable contributions to literary studies (Zakharov 2007: 28, 30). The scholar, arguing with the Russian Formalists but still benefiting from their theory, formulated and justified the understanding of the genre as a unity of what is said about the world and how it is done (Bakhtin 1996). Bakhtin managed to look into the nature of genre, taking into account both speech genres and genres of fiction. Genre is seen not only as a sum of properties, but as a certain way of organizing reality.

Later, Russian science continued this practical approach to conducting research within the framework of historical poetics into the genesis of several traditional genres, such as novella (Meletinsky 1990), medieval European novel (Meletinsky 1983), ancient Indian framed tale (Grintser 1963), French chivalric romance (Mikhailov 1976), European medieval genres of drama (Andreev 1989).

In 1986 Sergey Averintsev described how the very category of genre developed over the history. He argued that the term 'genre' has various meanings 
depending on the epoch, and the value of the category is not the same throughout the centuries of literary history. Averintsev identified three periods in the history of literature: antereflexive traditionalism with genre as part of the ritual, reflexive traditionalism, where genre is seen as a system of literary rules and patterns, and the epoch of individual creativity with the author's will prevailing over genre laws (Averintsev 1986).

From the theoretical perspective, the late twentieth and early twenty-first centuries suggested new genre-related categories that aimed to establish the communicative nature of the category of genre. To illustrate, 'metagenre' and 'supragenre' theories were worked out. 'Metagenre' is a category that allows a researcher to study a complex of texts such as utopia, dystopia, hagiography, detective, etc. (Podlubnova 2005). Due to a number of common semantic features, they are treated as similar genres, though in practice they take a number of forms: novel, short-story, tale, play, etc. In this case, applying a different category - metagenre - enables one to avoid ambiguity. In this case literary scholars have to deal with the correlation between the categories of genre and discourse. For example, Valery Tyupa identifies how the relation between genre and ritual (in Averitsev's terms) has been replaced by the relations between genre and discursive practices (Tyupa 2011). This approach can be used to illustrate how literary works that have the same theme or object (i.e. belonging to the same metagenre) differ in their message and the author's intention, ultimately taking the form of different genres. The other term, 'supragenre', refers to collections, cycles, anthologies, which, although not being independent genres, give information on genre perception. Still, these terms are not always transparent and may be used the other way round. For instance, Igor Smirnov treats 'sverkhzhanr' (supragenre) as 'metagenre' (Smirnov 2007).

It should also be mentioned that the contribution to genre nominations has lately been significant and genre labeling can be considered one of the rapidly developing areas. An example is a two-volume book of articles prepared by Ekaterinburg school of literary studies in 2008 (Dergachevskie chtenia 2008). This research is a step towards thorough and empirical studies of genres and their names.

\section{Current Challenges}

Despite the achievements in genre studies, the current state of genology and the research practices reveal a large number of pitfalls and challenges.

First of all, it should be mentioned that many scholars still try to work out the definition of the genre (Kabanova 2017) instead of using the existing ones. 
As a result, most academic papers on genre have to enumerate and discuss all the previous definitions. The problem is not the endeavours to define the genre, but the fact that they precede most research, while it should be the other way round: a new definition to the genre should become a result of some research into the category.

Another theoretical direction of studies that seems to have ended in deadlock is an attempt to develop a universal set of categories for any genre. Some scholars believe that it is possible to work out a list of genre properties that should be considered while analyzing any fictional genre. That means that researchers, though well aware of constraints of such attempts (Kukueva 2009: 5), are trying to pinpoint the model of genre as an abstract category.

Several such models have been suggested so far and are used as the basis for practical analysis. The bottom line that this type of research fails to take into account is Eikhenbaum's thesis that any element of the material can become the dominant and the genre-forming one. Recent fundamental research into the category of genre (Leiderman 2010) identifies a very complicated set of textual categories that should be borne in mind while attributing the genre to a text. Criticizing those papers that give preference to thematic, aesthetic, problematic aspects of a literary work as constituent for genre attribution, the researcher pinpoints a number of genre signals (Leiderman 2010: 117) that in fact comprise all the aspects of a literary work notwithstanding whether they play a role in genre definition or not. Finally, the researcher presents a theoretical model of genre as such (Leiderman 2010: 145) that turns out artificial and unable to help in the real analysis (Tarasova 2013: 95). The most dubious point, though, is the very principle of choosing the signals that are most commonly discussed in research instead of analyzing examples of genres themselves (Leiderman 2010: 120). Nevertheless, this study has become highly influential, and many postulates are taken for granted by modern scholars. This fact indicates what appeal theoretical models have for Russian researchers.

This theory-oriented approach might stem from mixing fictional and functional genres, which arises from advances in applied linguistics, i. e. from the theory of speech genres. While functional genres demonstrate a certain combination of composition, theme, and style, resulting from the communicate task and situation, genres of fiction emerge and develop under different conditions. That is why it is not likely that a category or a set of categories could be identified as central to genre definition. On the whole, there is a perfect genre theory in modern Russian science, but very few genres are actually studied within the framework of this theory.

From the practical perspective, there are also several pitfalls. Firstly, literary encyclopedias and dictionaries demonstrate a lack of unified approach 
to defining genres, which is essential for appropriate genre mapping. For example, the same encyclopedia, while defining the terms 'rasskaz' (short story) and 'novella', follows very different principles. In the former case, it is argued that the short story should be distinguished from the novella (Ninov 1971). In the latter, the difference is pronounced to be vague (Mikhailov 1968). Paradoxically, both entries attribute Maupassant's and Chekhov's short prose to the short story and to the novella, respectively. This situation is caused by encyclopedia entries being written by different scholars, which could not but lead to inconsistencies in genre treatment and genre overlapping due to different theoretical views on the genre as a whole. An illustration is the term 'roman' (novel), which in the entry on genre is argued to refer to various genre species: the novel in Late Antiquity, the chivalric romance and the novel in the modern understanding are different genres (Kozhinov 1964). Still, the encyclopedia does not provide a separate entry for the novel in Antiquity, but discusses it within the entry 'Roman' (Bogdanov \& Braginsky 1971).

What is more, scholars often ignore the western tradition of genre naming, which is crucial as the terminological systems of different languages do not coincide. For example, the entry on novella does not provide the western equivalents of the term (Mikhailov 1968). By referring to English and Russian sources only, the author does not inform the reader that 'novella' in the English language refers to a different genre that in Russian corresponds to 'povest' (which is longer than the novella). This leads to young researchers confusing terms and using them spontaneously, only adding to the vicious circle.

Then, in spite of the statement that genres are very different in different historical periods, the necessity to outline genre genesis dictates the emergence of entries describing metamorphoses of certain genres and to unifying different genres under the same name. That is why genre mapping becomes very complicated, as German Novelle is not contrasted with German Geschichte, and genre evolution is observed as a primarily theoretical issue.

The same situation is observed when dealing with the so-called genre homonymy (Lebedeva \& Rabenko 2018: 29). This happens, for example, with genres that travel to literature from folk or religious discourse. An example is the entry 'Legenda', which, on the one hand, is not differentiated from Sage and Legende in German tradition, and, on the other hand, unites the hagiographic, the folk and the literary genres (Chistov 1967). To make matters worse, the term 'legend' may denote not only genres, but also plots (Zueva 2001: 433) and texts using plots of folk legends (Kvyatkovsky 1966: 43).

What seems even more detrimental for the modern genre studies is the fact that many new genres or genres that originate from traditional ones are treated from the poetics perspective despite the theoretical claims concerning 
the necessity of a new approach to new genres. This approach dictates applying principles relevant to the analysis of literature prior to the nineteenth century. Instead, it seems logical that the texts should be compared to each other in order to define if they comply with some other, newer laws. This tendency is explained, in our view, by the fact that theoretical ideas of the Russian Formalists, though accepted, are rarely implemented to any actual material. They are used as a kind of museum exhibit: many scholars refer to them, but only a few actually try to put them into practice.

Unfortunately, even when the Russian Formalists' heritage is used, it can still lead to certain difficulties. Such is the tradition of describing particular genres. Following the example of the Formalists, as well as historical poetics scholars, who chose the well-established genre of the novella to illustrate the process of genre analysis, researchers of modern genres take it for granted that other genres, such as short story, tale, etc., also comprise a corpus of easily identified texts, which is not true.

Several words must be also said about choosing the deductive approach and moving from the general to the specific (Ryabkova \& Pestova 2016: 71), which is typical of most researchers. While for prescriptive poetics this principle is beneficial, as works of art are created according to the canon, in the nineteenth century this approach did not extend our knowledge of genres. In real practice, researchers choose the texts that correspond to their initial idea of the genre articulated in the previous epochs or concerning the previous epochs. In this case, all the dubious texts or the texts that diverge from the typical pattern are left aside. Although some conclusions may be true, they are by no means exhaustive. For example, the analysis of the novella genre only shows what kind of form an unusual event will take in this or that literary period (Ryabkova \& Pestova 2016: 71).

While studying less traditional genres that emerged only in the modern times, researchers are bound to choose the texts which comply with their intuitive original ideas of the genre. The results that they obtain inevitably support their initial speculations. Even though in some cases they may be right due to the 'genre memory', or ability of the genre to be easily recognized, inaccuracy and randomness of conclusions is very high. It leads to ridiculous mistakes. Thus, Sergey Esenin's narrative poem 'Cherny chelovek' (The Black Man) is analyzed as if it were a lyrical poem (Kopytov 2017: 384). The intext "Veliky Inkvizitor" (The Great Inquisitor), which Dostoevsky placed within the novel "Bratya Karamazovy" (The Brothers Karamazov) and which is called by its narrator, Ivan Karamazov, 'poema' (narrative poem), is by and large perceived as a legend. It has become traditional since the publication of Vasily Rozanov's article in 1891. On the basis of this text the features of legend are 
identified (Besonogova 2019). The author's term 'poema' is, on the contrary, often neglected. To avoid such inaccuracies, genre attribution should mainly involve the inductive approach, and genre nomination should follow studying literary texts.

Finally, it is sometimes a case when researchers misuse the very term 'genre' and substitute proper genre labels with metageneric or discourse terms. Thus such terms occur like a "historic-philosophic genre" in a book specifically devoted to genre (Myreeva \& Baisheva 2018). It may indicate that text analysis is disguised as genre studies only.

Most importantly, the situation is compounded by the fact that scholars tend to choose a genre from a writer's or an epoch's system and study it on its own, generalizing the results and claiming them to represent the genre on the whole. However, it is rarely possible to identify the properties of any genre without comparing it to other texts by the same author or belonging to the same epoch. Though the principles for such a comparison are difficult to lay down and it would definitely make the analysis more complicated and timeconsuming, it seems the only way to verify the results received.

Although there are many papers devoted to the history and the current state of genre studies, their critical assessment is still an exception. It is related to the fact that practical analyses of genres, generic systems, genre evolution are numerous, which makes it very difficult to assess the whole system of practices. Papers exploring different aspects of genre may be purely empirical and intuitive, without being based on solid theoretical foundation.

\section{Proposed Solutions}

An efficient and attainable solution to all the challenges outlined above could be using the comparative approach, which is not applied to the full when it comes to genre studies. Boris Yarkho contended in 1935 that the comparative method validated through statistical analysis is the only way to obtain any reliable results (Yarkho 2006: 7). Genres are not an exception: when they are studied in isolation, the results will be invalid and confusing. Identifying generic features requires mapping the genre(s), and comparing / contrasting to other genres is a prerequisite for genre studies. Thus, genre model will become three-dimensional, instead of one-dimensional.

The algorythm of modern genres studies, in our opinion, should involve several steps. During the first stage, several groups of texts written by the same author should be identified according to the same principle. It is most reasonable to choose the author's label (if any). Then the text within the 
possible group should be compared against each other in order to point out their integral features. Then, the same procedure is applied to another group of texts, after which the two groups are contrasted with a view to identifying the differences. Some of the categories may coincide for two genres, but there will certainly be disintegrating properties. One should bear in mind that to belong to a generic grouping the text does not have to necessarily possess all the qualities, but their number should be sufficient for the reader to easily attribute the text as belonging to this or that genre.

Only after that can the texts without the author's label be generically attributed. It should be remembered, however, that the writer's way of labelling literary texts may not be conventional, especially if genres are at the initial stage of formation. In this case the procedure will enable the researcher to absract from conventions and analyse the groupings as such. After that, a genre is contrasted to other genres used by the same writer. Then, a genre pattern functioning within one system (writer) should be compared and/or contrasted to a similar genre in a different system (writer) so as to verify the results and establish the pattern for a particular national literature. In a perfect situation, the genre sychnrony should be supported by a diachronical analysis of the pattern's evolution within the culture.

Then, these groups can be compared with the groups identified in contemporary works in other languages. The features of the genre should be ascertained only after such thorough analysis to dispose of all accidental features or those features that could be indicators of an individual author's style rather than genre features.

It seems that such algorithm, when applied to nineteenth century literature at least, complies well with what Lotman recquired from a scholar stating that in order to define the features of the phenomenon studied, it is possible to obtain certain sets of features by comparing objects many times and with different sets of objects (Lotman 2012b: 770). This approach is more widely used in linguistic text analysis (Bogdanova 2008), and is being currently applied by one of authors of the present paper (Tuliakova 2017; Tuliakova 2020) on the material of the nineteenth century Russian short prose, which so far has resulted in a possibility of distinguishing between several pseudo-folk genres and describing their evolution.

\author{
Natalia Nikitina \\ nanikitina@hse.ru \\ HSE University \\ Department of Foreign Languages \\ 16 Soyuza Pechatnikov Street, St Petersburg, 190121 \\ RUSSIA
}


Genre Studies in Russian Literary Research: Achievements and Challenges

\author{
Natalia Tuliakova \\ ntulyakova@hse.ru \\ HSE University \\ Department of Foreign Languages \\ 16 Soyuza Pechatnikov Street, St Petersburg, 190121 \\ RUSSIA
}

\title{
Bibliography
}

Akhrieva, L. 2014. Kontseptsia zhanra v statyakh Yu.N. Tynyanova "Literaturny fakt" i "O literaturnoy evolyutsii" - Uchenye zapiski Petrozavodskogo gosudarstvennogo universiteta, 1(138), 78-80.

Andreev, M. 1989. Srednevekovaya evropeyskaya drama. Moskva: Iskusstvo.

Averintsev, S. 1986. Istoricheskaya podvizhnost' kategorii zhanra: opyt periodizatsii - Istoricheskaya poetika. Moskva: Nauka, 104-116.

Bakhtin, M. 1996. Problema rechevykh zhanrov - Bakhtin, M. Sobranie sochineny, T. 5. Moskva: Russkie slovari, 159-206.

Besonogova, S. 2019. Funktsionirovanie pretsedentnykh tekstov iz Biblii v glavakh romana "Bratya Karamazovy" "Veliky inkvizitor” i "Kana Galileyskaya” - Khudozhestvenny tekst glazami molodykh. Yaroslavl’: Yaroslvsky gosudarstvenny universitet, 11-16.

Bogdanov, V., Braginsky, I. 1971. Roman - Kratkaya literaturnaya entsiklopedia. T. 6. Moskva: Sovetskaya entsiklopedia, 350-362.

Bogdanova, N. 2008. Strukturno-semanticheskaya organizatsia khudozhestvennykh tekstov v ikh zhanrovoy spetsifike. Dissertatsia. Minsk.

Burlina, E. 1987. Kul'tura i zhanr. Saratov: Izdatel'stvo Saratovskogo universiteta.

Chistov, K. 1967. Legenda - Kratkaya literaturnaya entsiklopedia. T. 4. Moskva: Sovetskaya entsiklopedia, 90-91.

Dergachevskie chtenia. 2008. Ekaterinbrug: Ural'sky gosudarstvenny universitet.

Domínguez, C. 2009. Genres as Sites of Intercultural Encounters: New Perspectives for a Comparative Genre Theory. - Caitele Echínox / Cahiers de l'echínox, 16: 5160 .

Eikhenbaum, B. 1927. O.Genri i teoria novelly - Eikhenbaum, B. Literatura: teoria, kritika, polemika. Moskva: Priboy, 156-209.

Eikhenbaum, B. 1969. O proze. Leningrad: Khudozhestvennaya literatura.

Freidenberg, O. 1936. Poetika syuzheta i zhanra. Leningrad: Goslitizdat.

Grintser, P. 1963. Dreveneindiyskaya proza. Moskva: Izdatel'stvo vostochnoy literatury.

Kabanova, N. 2017. Opredelenie ponyatia 'zhanr' v sovremennoy zhanrologii Gumanitarno-pedagogicheskoe obrazovanie, 3(3), 35-43.

Kopytov, O. 2017. Literaturnye zhanry kak obyekt lingvistiki - Stilistika: mova, maulenie i tekst. Minsk: Adukatsia, 380-388. 


\section{TULIAKOVA, NIKITINA}

Kozhinov, V. Zhanr - Kratkaya literaturnaya entsiklopedia. T. 2. Moskva: Sovetskaya entsiklopedia, 914-917.

Krylov, V. 2008. Spory o zhanrovykh nominatsiyakh v russkoy kritike XIX veka Dergachevskie chtenia, T. 1. Ekaterinburg: Ural'sky gosudarstvenny universitet, 222-226.

Kukueva, G. 2009. Lingvopoeticheskaya tipologia tekstov maloy prozy (na materiale rasskazov V.M. Shukshina): Dissertatsia. Barnaul.

Kvyatkovsky, A. 1996. Poetichesky slovar'. Moskva: Sovetskaya entsiklopedia.

Lebedeva N., Rabenko, T. 2018. Zhanrovoe imya kak faktor stabilizatsii rechevogo zhanra - Vestnik Tomskogo gosudarstvennogo universiteta, 437, 29-35. https://doi. org/10.17223/15617793/437/4

Leiderman, N. 2010. Teoria zhanra. Ekaterinburg: Rossiyskaya akademia obrazovania.

Lotman, Yu. 1970. Struktura khudozhestvennogo teksta. Moskva: Iskusstvo.

Lotman, Yu. 2012a. Literaturovedenie dolzhno byt' naukoy - Lotman, Yu. O russkoy literature. Sankt-Peterburg: Iskusstvo, 756-765.

Lotman, Yu. 2012b. O tipologicheskom izuchenii literatury - Lotman, Yu. O russkoy literature. Sankt-Peterburg: Iskusstvo, 766-773.

Meletinsky, E. 1983. Srednevekovy roman. Moskva: Nauka.

Meletinsky, E. 1990. Istoricheskaya poetika novelly. Moskva: Nauka.

Mikhailov, A. 1968. Novella - Kratkaya literaturnaya entsiklopedia. T. 5. Moskva: Sovetskaya entsiklopedia, 306-308.

Mikhailov, A. 1976. Frantsuzsky rytsarsky roman $i$ voprosy tipologii zhanra v srednevekovoy literature. Moskva: Nauka.

Miliutin, D. 1831. Opyt literaturnogo slovaria. Moskva.

Myreeva, A., Baisheva, A. 2018. Zhanr v khudozhestvennom mire N.A. Luginova. Yakutsk: SVFU.

Ninov, A. 1971. Rasskaz - Kratkaya literaturnaya entsiklopedia. T. 6. Moskva: Sovetskaya entsiklopedia, 190-193.

Ostolopov, N. 1821. Slovar' drevney i novoy poezii. Sankt-Peterburg.

Petrovsky, M. 1927. Morfologia novelly. Moskva: Gosudarstvennaya akademia khudozhestvennykh nauk.

Podlubnova, Yu. 2005. Metazhanry v russkoy literature 1920 - nachala 1940-kh godov. Ekaterinburg.

Reformatsky, A. 1922. Opyt analiza novellisticheskoy kompositsii. Moskva: OPOYAZ.

Ryabkova, A., Pestova, N. 2016. Nemetskaya romanticheskaya novella kak osoby literaturny zhanr - Romanskie i germanskie yazyki. Ekaterinburg: Ural'sky gosudarstvenny universitet, 69-73.

Shklovsky, V. 1974. Tetiva. O skhodstve neskhodnogo - Shklovsky, V. 1974. Sobranie sochineny. T. 3. Moskva: Khudozhestvennaya literatura, 465-784.

Smirnov, I. 2007. Fantasticheskoe kak (sverkh)zhanr - Novy filologichesky vestnik, 2(5), $19-33$.

Soina, A. 2019. K voprosu o 'yadre' i 'periferii' zhanra - Perevodchesky diskurs. Simferopol’: Arial, 361-366. 
Genre Studies in Russian Literary Research: Achievements and Challenges

Tamarchenko, N. 2012. Predislovie - Teoria literaturnykh zhanrov. Moskva: Akademia, $3-5$.

Tarasova, I. 2013. Kognitivnye modeli zhanra - Istoricheskaya poetika zhanra, 5, 94101.

Tomashevsky, B. 1925. Teoria literatury. Leningrad: Gosudarstvennoe izdatel'stvo.

Tsytsarkina, N. 2008. Kognitivnaya osnova zhanrov v khudozhestvennykh i nekhudozhesvennykh tekstakh - Problemy zhanra $v$ sovremennom literaturovedenii. Kurgan: KGU, 105-110.

Tuliakova, N. 2018. Sviatochny rasskaz i legenda v tvorchestve D.N. Mamina-Sibiriaka: sopostavitel'ny analiz zhanrov - Vestnik Tomskogo gosudarstvennogo universiteta, 432, 24-31.

Tuliakova, N. 2020. Literary legend in the early $19^{\text {th }}$ century Russian literature: genre labeling and genre formation - Russian Literature, 111-112, 35-59. https://doi. org/10.1016/j.ruslit.2020.03.002

Tynyanov, Yu. 1977. O literaturnoy evolyutsii - Tynyanov, Yu. Poetika. Istoria literatury. Kino. Moskva: Nauka, 270-281.

Tyupa, V. 2011. Zhanr i diskurs - Kritika i semiotika, 15, 31-42.

Veselovsky, A. 2004. Istoricheskaya poetika. Moskva: URSS.

Yarkho, B. 2006. Metodologia tochnogo literaturovedenia. Moskva: Yazyki slavyanskikh kul'tur.

Zakharov, V. 2007. Problema zhanra v 'shkole’ Bakhtina - Russkaya literatura, 3, 119130.

Zueva, T. 2001. Legenda - Literaturnaya entsiklopedia terminov i ponyaty. Moskva: Intelvak, 432-434. 